\title{
ALGAE, CYANOPROKARYOTA AND AQUATIC VEGETATION OF LAKE TRUBYN (DESNA OXBOW SYSTEM, UKRAINE)
}

\author{
Levanets A.A. ${ }^{1}$, Gromakova A.B. ${ }^{2}$, Shiyan N.N. ${ }^{3}$, van Rensburg L. ${ }^{1}$ \\ ${ }^{1}$ School for Environmental Sciences and Development, Botany Dept., Private Bag \\ X6001, North-West University, Potchefstroom 2520, Republic of South Africa \\ ${ }^{2}$ V.N. Karazin Kharkov National University, Biological Faculty, Botany Dept., 4 \\ Maydan Svobody, Kharkov, 61077 Ukraine \\ ${ }^{3}$ M.G. Kholodny Institute of Botany of National Academy of Sciences of Ukraine, 2 \\ Tereschenkivska Str., Kyiv-1, 01601 Ukraine. Tel.: +38 (044) 234-51-57; Fax: \\ +38(044) 234-40-41; e-mail: herbarium-kw@ukr.net
}

\begin{abstract}
Floristical spectrum of aquatic plants forms under influence of natural, historical and geographical factors. Higher aquatic vegetation as well as algal play an important ecological, hydrological and economical role. But aquatic ecosystems are very affected by influence of direct anthropogenic factors as well as indirect through the transformation of river basins. This is why monitoring of higher aquatic and algal vegetation of such closed systems like freshwater lakes is so important for understanding of processes which take place in lakes as well as for scientific prognostication of lake ecosystems changes.
\end{abstract}

\section{Introduction}

Desna is a left tributary of Dnipro River, and one of the biggest Ukrainian rivers, which originates on the Smolensk heights (Smolensk Region, Russia). From the $1130 \mathrm{~km}$ of total length $591 \mathrm{~km}$ are situated on the territory of Ukraine. Total area of Desna River basin covers $88,900 \mathrm{~km}^{2}$. River flood-lands are highly swamped with a big number of channels and oxbow lakes, some of which are characterized by unique floristical complexes. Studies of true-aquatic and coastalaquatic flora of this region, which has an important economic significance for Ukraine and being characterized by presence of considerable number of rare and relic species and communities, were carried out irregularly. The information about some species of aquatic flora of Desna and its flood-lands is present in numerous 
works (Dubyna and Moroz, 1977; Dubyna and Semenikhina, 1978; Semenikhina, 1979; Balashov et al., 1980; Mulyarchuk, 1980), but lower reaches of the river remain better studied until now (Vakulenko, 1935; Desna, 1964). In 1977-1980 Semenikhina investigated flora and vegetation of Desna and its oxbow and flood-land lakes and channels on Ukrainian territory (Dubyna and Semenikhina, 1978; Semenikhina, 1979, 1982 a, b; Balashov et al., 1980; Shelyag-Sosonko and Semenikhina, 1984). Some of the lakes were found to be very interesting in formation of floristical complexes, which were studied in detail (Semenikhina, 1982a; Shelyag-Sosonko and Semenikhina, 1984).

Lake Trubyn is a unique object for the studies of aquatic vegetation changing dynamics because of its flora and vegetation monitoring had started in 1970s and continues until now. K. Semenikhina studied it for the first time during investigations of aquatic and coastal-aquatic flora and vegetation of River Desna basin (Semenikhina, 1979; Shelyag-Sosonko and Semenikhina, 1984). In 1990 N. Shyian started monitoring of floristical composition and vegetation dynamics of this lake.

\section{Materials and Methods}

Trubyn Lake is the biggest oxbow lake of Desna flood-lands situated in environs of Grushivka village (Borzna District, Chernigiv Region). It is arised in the natural depression of slightly elongated shape and has bifurcated northern part. Lake's length is about $7 \mathrm{~km}$, width is nearly $0.6 \mathrm{~km}$, and total area is about $40 \mathrm{ha}$, with 5-7 m depth. Lake feeding is mixed. It occurs by precipitation and connection with water bodies, Byhov Lake and Bereza River which sometimes dries up. Also it's being fed by water supply from Desna during big spring floods. Water temperature in summer time is $19-20.5^{\circ} \mathrm{C}$ on $0.5 \mathrm{~m}$ depth from surface, and near the bottom it's decreased up to $16-17.5^{\circ} \mathrm{C}$. During the winter time lake is covered by ice. Water transparency is up to $0.85 \mathrm{~m}$. Lake's bottom is covered by sandysilty deposits. Two settlements and holiday resort are situating on the lake shores (Geographical, 1989 and 1993; Shelyag-Sosonko and Semenikhina, 1984).

Our study was carried out by detailed-routeing method with consideration of peculiarities and features of higher aquatic flora and vegetation investigations (Potulnytsky et al., 1973; Belavskaya, 1979; Hejny, 1981; Katanskaja, 1981; Semenikhina, 1982b). Funds of KW, KWH, KWU and Mykola Gogol Nizhyn State University were used for preparation of floristical list of aquatic plants. Ecological groups of aquatic macrophytes were distinguished according to the classification of Potulnytsky and colleagues (Potulnytsky et al., 1973).

Algological material for the present work was collected in the course of the field trip during September 1999. The samples were collected and preceded according to standard algological methods (Vodorosli, 1989). Cyanoprocaryotes and algae identified in living and fixed (by $4 \%$ formalin) states both in the algological samples and in the cultures. Species composition of diatoms was 
examined using permanent slides with pleuraco. Species were identified under light microscopes equipped with planapochromat immersion objectives. The following taxonomic literature served for the identification of cyanoprocaryotes and algae: Geitler, 1932; Elenkin, 1938-1949; relevant issues of the "Vyznachnyk prisnovodnykh vodorostey Ukrainskoyi SSR" (1938-1994), "Die Binnengewässern. Das Phytoplankton des Süsswassers" (Huber-Pestalozzi 1969, 1972, 1983) and others.

\section{Results and Discussion}

Aquatic and coastal-aquatic flora.

According to our results, analyses of herbarium collections and literature data, aquatic and coastal-aquatic vegetation of Lake Trubyn encountered 89 species of higher aquatic plants belonging to 62 genera and 40 families (Table 1). Three species of them $(3.37 \%$.) belong to the vascular cryptogams (Equisetum palustre L. Salvinia natans (L.) All., Thelypteris palustris Schott). About, 53.93\% of species composition of Trubyn Lake flora belong to 11 families. The most represented families were Potamogetonaceae (9 species), Cyperaceae (6), Asteraceae (5), at the same time Hydrocharitaceae, Poaceae, Ranunculaceae, Lemnaceae families were represented by 4 species, and Lamiaceae, Nymphaeaceae, Primulaceae, Juncaceae had only 3 species each. All other families consist of 1 to 2 species in the lake flora and all together encountered by 41 species (46.07\% from total number of species) (Table 1).

Table (1): Systematical composition of Lake Trubyn aquatic and coastal aquatic flora

\begin{tabular}{|c|l|c|c|c|}
\hline $\mathbf{N}$ & \multicolumn{1}{|c|}{ Family } & $\begin{array}{c}\text { Number of } \\
\text { genera }\end{array}$ & $\begin{array}{c}\text { Number of } \\
\text { species }\end{array}$ & $\begin{array}{c}\text { \% from total } \\
\text { number of species }\end{array}$ \\
\hline 1 & Potamogetonaceae & $\mathbf{1}$ & $\mathbf{9}$ & $\mathbf{1 0 . 1 1}$ \\
\hline 2 & Cyperaceae & 3 & 6 & 6.74 \\
\hline 3 & Asteraceae & 3 & 5 & 5.62 \\
\hline 4 & Hydrocharitaceae & 4 & 4 & 4.49 \\
\hline 5 & Poaceae & 3 & 4 & 4.49 \\
\hline 6 & Ranunculaceae & 3 & 4 & 4.49 \\
\hline 7 & Lemnaceae & 2 & 4 & 4.49 \\
\hline 8 & Lamiaceae & 3 & 3 & 3.37 \\
\hline 9 & Nymphaeaceae & 2 & 3 & 3.37 \\
\hline 10 & Primulaceae & 2 & 3 & 3.37 \\
\hline 11 & Juncaceae & 1 & 3 & 4.37 \\
\hline 12 & Others & 35 & 41 & 100 \\
\hline & Total & 62 & 89 & \\
\hline
\end{tabular}

From 62 genera representing Trubyn Lake flora the most diverse are Potamogeton (9) and Carex (4). At the same time a number of genera consist of 3 (Bidens, Lemna, Juncus) or 2 (Batrachium, Ceratophyllum, Galium, Glyceria, Lysimachia, Myriophyllum, Nymphaea, Typha, Sparganium, Stellaria) species. All another 47 genera $(52.81 \%)$ of lake flora were represented only by single species. 
In comparison with floristically composition of Desna River basin which encountered 111 species (Semenikhina, 1982b), species composition of the lake quantitatively less (89 species). But at the same time Potamogetonaceae and Cyperaceae occupy the leading place as within the river basin flora as well. The peculiarity of Lake Trubyn flora in comparison with the flora of Desna River basin is that in the lake flora Poaceae, Ranunculaceae, Lemnaceae families lost their positions to Asteraceae and Hydrocharitaceae. Besides a prominent place in the flora of the lake plays representatives of the Nymphaeaceae and Juncaceae families. This distribution of families from the one side, characterizes this water body as a relatively closed ecosystem, but from the other side it indicates the changes in the flora of the lake. And these changes lead to ruderalisation of coastal-aquatic vegetation and to changes in the hydrological regime of water body (in the last 10 years northern part of the lake turned into swamp).

By the ecological features and morphology plants from Lake Trubyn divided in two groups: true aquatic (hydatophytes, completely submerged plants and hemihydatophytes, species with floating on the surface of the water leaves) and coastal-aquatic (air hydrophytes, root part of which is wholly or partially located in the water, but a upper sprouts above the water). Within these types allocated eight subgroups on the basis of their adaptation to the conditions of growth and rhythm of the development (Potulnytsky et al., 1973). Namely: Ceratophylides (plants are not rooted, with completely submerged vegetative sprouts), Elodeides (plants are rooted, with completely submerged vegetative sprouts), Lemnides (plants are not rooted, with floating on the surface of the water leaves or leaves-like vegetative sprouts), Nympheides (plants are rooted, with floating on the surface of the water leaves), Alismatides (shallow waters plants, that survive deep water stage for a long time), Phragmitides (tall shallow waters plants, that survive deep water stage for a short time), Elacineides (low shallow waters and coastal line plants, that survive deep water stage for a limited time), Carexides (plants with long vegetation period, that survive deep water stage for a limited time). As seen from the Table 2, in the floristic list of the lake coastal-aquatic plants dominated (59 species -66.29 $\%$ ), that form along the bank mosaic of associations which can be 1-3 m width in the southern part up to $10-15 \mathrm{~m}$ in the northern part. Over the past 10 years we have seen an increase of coastal-aquatic vegetation stripe, which is primarily associated with shallowing of the lake, especially its northern branches.

Analysis of the species areas of distribution that grow in the Lake Trubyn showed that the vast majority of them are Holarctic (32 species, 35.96\%) and European (17 species, 19.1\%) habitat types (Table 3). Eurasian and Multiregional species have a significant proportion according to the type of area distribution (15 species each). The least represented European-Siberian (Carex acuta L., Ceratophyllum submersum, Sparganium erectum L.) and North-American (Elodea canadensis) species. 
Table (2): Ecological groups of higher aquatic and coastal aquatic vegetation in Lake Trubyn flora

\begin{tabular}{|c|c|c|c|c|c|c|c|c|}
\hline \multirow[b]{3}{*}{$\begin{array}{l}\text { Number of } \\
\text { species }\end{array}$} & \multicolumn{4}{|c|}{ True-aquatic species } & \multirow{2}{*}{\multicolumn{4}{|c|}{$\begin{array}{c}\text { Coastal-aquatic species } \\
\text { Aerohydrothytes }\end{array}$}} \\
\hline & \multicolumn{2}{|c|}{ Hydatophytes } & \multicolumn{2}{|c|}{$\begin{array}{c}\text { Hemihydato- } \\
\text { phytes }\end{array}$} & & & & \\
\hline & 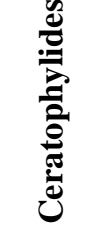 & 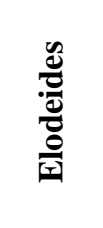 & 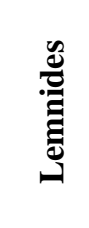 & 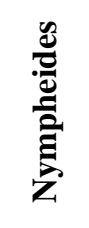 & 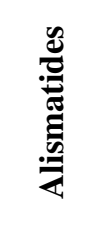 & 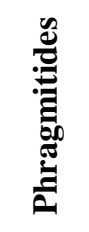 & 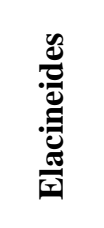 & 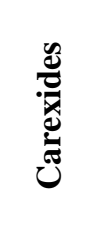 \\
\hline Total & 3 & 12 & 7 & 8 & 11 & 7 & 19 & 22 \\
\hline $\begin{array}{c}\% \text { from total } \\
\text { number of } \\
\text { species }\end{array}$ & 3.37 & 13.48 & 7.87 & 8.99 & 12.36 & 7.87 & 21.35 & 24.72 \\
\hline In total & \multicolumn{4}{|c|}{30 species $-33.71 \%$} & \multicolumn{4}{|c|}{59 species $-66.29 \%$} \\
\hline
\end{tabular}

Table (3): Lake Trubyn aquatic vegetation according to the species types of areas of distribution

\begin{tabular}{|l|c|c|}
\hline \multicolumn{1}{|c|}{$\begin{array}{c}\text { Type of area of } \\
\text { distribution }\end{array}$} & Number of species & \% from total number of species \\
\hline Holarctic & 32 & 35.96 \\
\hline European-Asian & 15 & 16.85 \\
\hline European & 17 & 19.1 \\
\hline European-Siberian & 3 & 3.37 \\
\hline Mediterranean & 6 & 6.74 \\
\hline North-American & 1 & 1.12 \\
\hline Multiregional & 15 & 16.85 \\
\hline In total & 89 & 100 \\
\hline
\end{tabular}

Among the species of the Lake Trubyn a special attention deserves a rare species of ferns Salvinia natans which is included in the list of species protected by the Berne Convention. In Ukraine it is protected by Plant Life Low and included to the Third Edition of Red Data Book of Ukraine (Red, 2009).

Salvinia natans: Tertiary relict species whose natural habitat is disjunctive and provisionally divided into two parts, East-Asian (Malay Archipelago, China, Japan, Manchuria) and European (Southern and Eastern Europe). This species in Ukraine sporadically occurs in Dniper, Desna, Pivdenny Bug, Siversky Donets River valleys and in Danube Delta. 
Long time for Desna Basin this species was noted only from several sites downstream Desna River and only since 1979 it is known for Trubyn Lake (Semenikhina, 1979, 1982b; Shelyag-Sosonko and Semenikhina, 1984). Within the lake $S$. natans especially abundant in the northern part. In June-July a single plants occurs here, and from late August through October, areas in a few $\mathrm{m}^{2}$ richly covered by $S$. natans. At that period maximum of species vegetation existed but this species does not form pure coenoses within the lake. Usually $S$. natans in the Lake Trubyn grows as a member of widespread Hydrocharitetum morsus-ranae Van Langend 1935 association and fragments of Salvinio-Hydrocharitetum (Oberdorfer, 1957) Boscaiu 1966 and Spirodelo-Salvinietum natantis Slavnić 1956 associations, which we will examine later.

\section{Vegetation of Lake Trubyn.}

During the compilation of the modern Lake Trubyn vegetation map we've taken the map published in 1984 by Yu.R. Shelyag-Sosonko and K. Semenikhina, who first conducted a mapping (Shelyag-Sosonko and Semenikhina, 1984). We made some changes and additions because for more than 20 years borders and distribution of many associations have changed (Fig.1). In addition to the lake, for the first time we proposed scheme of coenoses distribution of northern part of lake near northern neighborhood of Grushivka village (Fig.2).

Coastal-Aquatic Vegetation.

Monodominant Phragmitetum communis (Gams 1927) Schmale 1939 and Typhetum angustifoliae Pignatti 1953 associations were prevailed according to areas of distribution in Lake Trubyn. They are belongs to the class PhragmitiMagnocaricetea Klika in Klika et Novak 1941.

Monodominant association Phragmitetum communis occupied the largest areas in northern part of the lake. It is related with shallow waters and silty-sandy deposits (depth of water here is $0.8 \mathrm{~m}$ ). Herbage height here is about 2-3 $\mathrm{m}$, singlestage coenoses with uniform composition. General projective vegetation cover was about $90-100 \%$ (in places with more sparse grass - up to $60 \%$ ). In this associations hemihydatophytes Hydrocharis morsus-ranae L., Lemna minor L., Spirodela polyrrhiza (L.) Schleid., Stratiotes aloides L. and hydatophytes Ceratophyllum demersum L., Myriophyllum spicatum L. were the assectators with projective vegetation cover up to $10 \%$. Salvinia natans, Nuphar lutea (L.) Smith, Nymphaea candida C.Presl, Utricularia vulgaris L., Elodea canadensis Michx were covered up to 1-5\% of area. Acorus calamus L., Carex riparia Curtis, Potentilla palustris (L.) Scop., Rumex hydrolapathum Huds., Glyceria maxima 


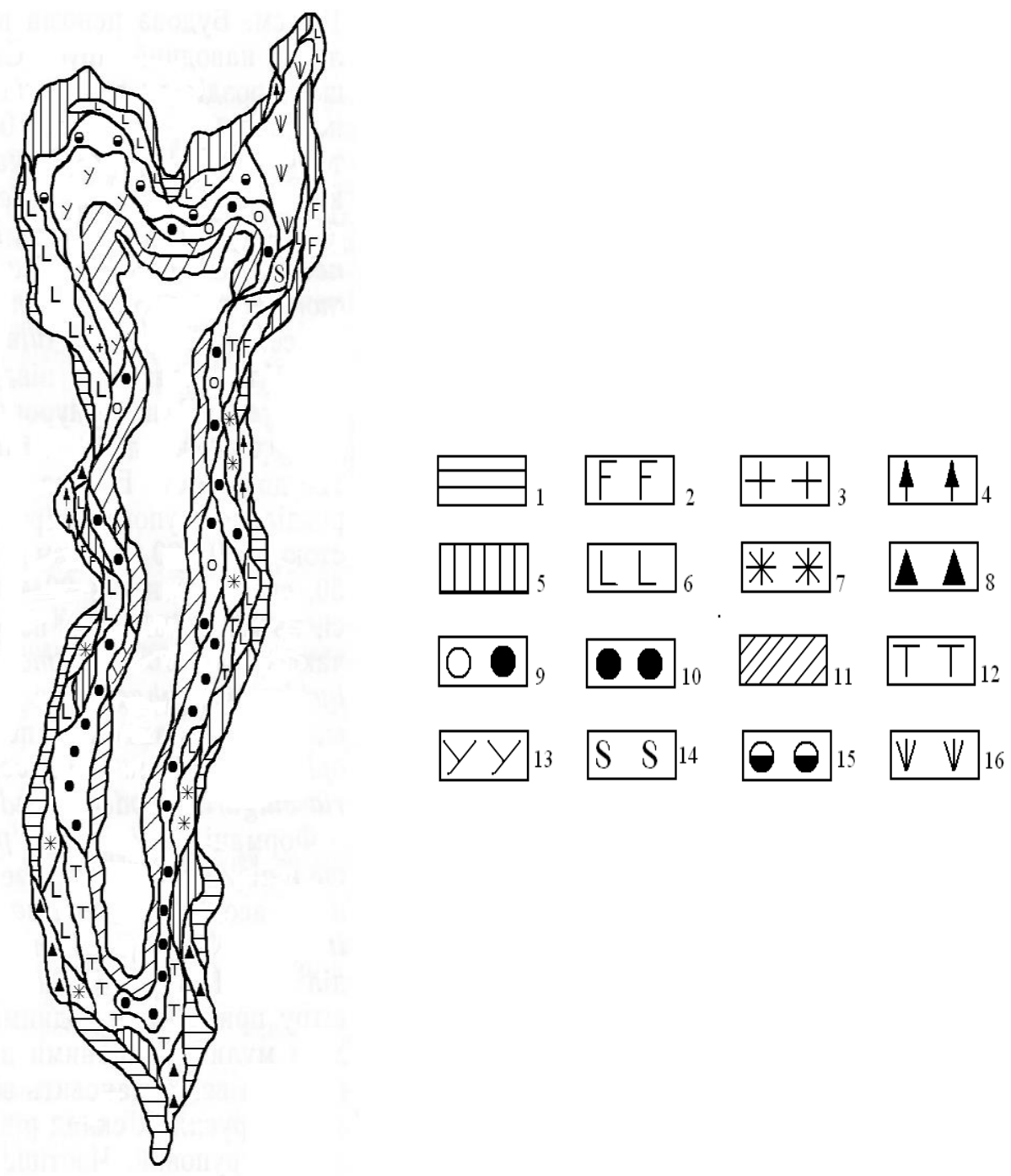

Figure (1): Vegetation map of Lake Trubyn. Associations: 1 - Carici acutaeGlycerisetum maximae; 2 - Sagittario-Sparganietum emersi; 3 - Rorippo amphibiaeOenanthetum aquaticae; 4 - Butomo-Saggitarietum sagittifoliae; 5 - Phragmitetum communis; 6 - Typhetum angustifoliae; 7 - Scirpetum lacustris; 8 - Acoretum calami; 9 - Nupharo lutei-Nymphaetum albae; 10 - Myriophyllo-Nupharetum; 11 - Potametum lucentis; 12 - Elodeetum canadensis; 13 -Ceratophylletum demersi; 14 - LemnoSpirodeletum polyrhizae; 15 - Hydrocharitetum morsus-ranae; 16 - HydrocharitioStratiotetum aloides. 


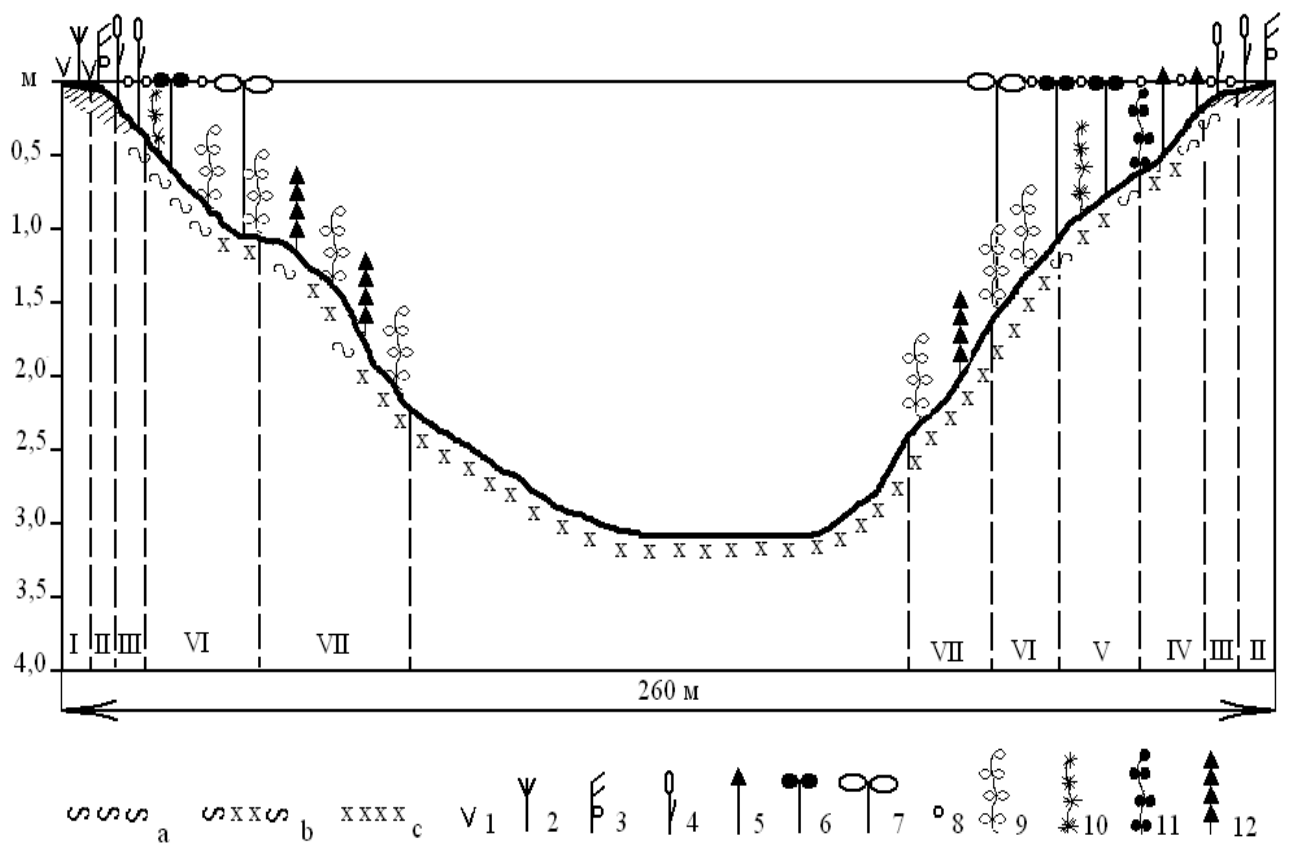

Figure (2): Scheme of aquatic vegetation coenoses distribution in Lake Trubyn. a - peat-silty ground deposits; $b$ - silty-sandy ground deposits; $c$ - sandy ground deposits; 1 - Carex acuta; 2 - Glyceria maxima; 3 - Phragmites australis; 4 - Thypha angustifolia; 5 - Sagittaria saggitifolia; 6 - Nuphar lutea; 7 - Nymphaea alba; 8 Spirodela polyrhiza; 9 - Potamogeton perfoliatus; 10 - Myriophyllum verticilatum; 11 Elodea canadensis; 12 - Potamogeton lucens. Associations: I - Carici acutae-

Glycerisetum maximae; II - Phragmitetum communis; III - Typhetum angustifoliae; IV - Sagittario-Sparganietum emersi; V - Myriophyllo-Nupharetum; VI - Nupharo luteiNymphaetum albae; VII - Potametum lucentis.

(C.Hartm.) Holmberg, Alisma plantago-aquatica L. were grew closer to the bank of lake (depth 0.2-0.3 м) and on the hummocks. Within of this association in northern part of Trubyn Lake Myriophyllum spicatum L., Nymphaea alba L., Ceratophyllum submersum L. were found (singly or in a small number). In recent years in northern part of the lake was noted very active growth of Phragmitetum communis association.

Behind Phragmitetum communis strip, in ecotopes with sandy-silty deposits (0.5-1.0 m depth) monodominant Typhetum angustifoliae association was distributed. Herbage height here is dense, with projective vegetation cover 80-95 $\%$ (dominant species covered $65-80 \%$ of area), single-stage coenoses with uniform composition. Floristical composition was very similar to previous association, except of Typha latifolia L., Sparganium erectum L. S. emersum 
Rehmann and Glyceria maxima. Coenoses of described associations stretched along the coast in the form of stripes, sometimes they are expands or contracts, in some places interrupted.

Carici acutae-Glycerisetum maximae (Jilek et Valisek, 1964) Shelyag, V. Sl. et Sipaylova 1985 association was much inferior to that area of two previous communities. It is narrow strip along the entire coastline, often interrupted. General projective vegetation cover here was about 75-90\%, (where Carex acuta - $40 \%$, Glyceria maxima - 50\%). Sparganium erectum L., Bidens cernua L., B. tripartita L., Butomus umbellatus L., Lemna minor, L. trisulca L., Spirodela polyrrhiza, Calystegia sepium (L.) R.Br. were noted within these communities. On the shores of the lake within the settlements (where part of vegetation was completely destroyed by livestock and used as a watering place) were noted Sonchus palustris L., Urtica dioica L., Solanum nigrum L., Tussilago farfara L. for Carici acutae-Glycerisetum maximae.

Shallow places of lake in areas where there are no marked associations occupied by fragments of Sagittario-Sparganietum emersi R. Tx. 1953, Rorippo amphibiae-Oenanthetum aquaticae (Soó, 1928) Lohmeyer 1950, ButomoSaggitarietum sagittifoliae Losev in Losev et Golub 1988, Scirpetum lacustris Schmale 1939, Acoretum calami Eggler 1933 associations (Fig.1).

True-Aquatic Vegetation.

Nupharo lutei-Nymphaetum albae (Nowinski, 1930) Tomasz. 1977, Myriophyllo-Nupharetum W. Koch 1926, Potametum lucentis Hueck 1931 All., Elodeetum canadensis Eggler 1933 All., Ceratophylletum demersi (Soó,1928) Eggler 1933 associations were most common among aquatic vegetation of class Potametea Klika in Klika et Novak 1941 in Trubyn Lake.

Nupharo lutei-Nymphaetum albae association was distributed along whole coastline. Along the eastern lake bank and in its northern part aquatic coenoses were confined to shallow waters with silty-sandy ground deposits (water depth $1.2-1.5 \mathrm{M})$. The structure of the coenoses was simple - clearly identified abovewater horizon with uniform composition. General projective vegetation cover was about $90-100 \%$ (where dominant 40-60 \%, subdominant 25-30\%). Ceratophyllum demersum, C. submersum, Elodea canadensis, Hydrocharis morsus-ranae, Lemna minor, Potamogeton perfoliatus, P. natans, L., Potamogeton compresus L., P. lucens L., Spirodela polyrrhiza, Salvinia natans were noted as a species with vegetation cover up to $10 \%$, and Nymphaea candida, lemna gibba, Batrachium rionii, Potamogeton nodosus Poir. were noted as a single specimen.

Myriophyllo-Nupharetum association distributed mostly in southern part of the lake and along western coastline. It confined to sandy-silty ground deposits and to 1.2-2.0 m water depths. The structure of the coenoses was from 2-layers, composition consisted from separate groups. General projective vegetation cover was about 70-80 \% (where Nuphar lutea 40-50 \%, Myriophyllum verticillatum up 
to 10-15\%). Spirodela polyrrhiza, Lemna minor, Hydrocharis morsus-ranae, Nymphaea alba, N. candida grow here within above-water level, Potamogeton perfoliatus, P.crispus L., P. lucens L., Potamogeton compresus L., Myriophyllum spicatum, Utricularia vulgaris, Elodea canadensis grow within submerged level.

Potametum lucentis association was widely distributed in Trubyn Lake and presented here by two subassociations - Potametum lucentis subass. typica Dubyna 2006 and Potametum lucentis subass. ceratophylletosum demersi Dubyna 2006 (Dubyna, 2006).

Coenoses of standard Potametum lucentis associations have the form an almost continuous stripe which was located by the waters and in well-warmed sites (water depth was 0.2- 1.0 (1.60) $\mathrm{M}$, silty-sandy ground deposits). Herbage there was sparse, projective vegetation cover was about 50-70\%, participation of dominant was 30-50 \%. Spirodela polyrrhiza, Lemna minor, L. trisulca L. Potamogeton perfoliatus, Myriophyllum spicatum, Ceratophyllum demersum were most common species and they covered 5-15\% of area.

Occasionally there were communities in which participation of Ceratophyllum demersum was 20-25\% (Potametum lucentis subass. ceratophylletosum demers). In the lake they were confined to the shallow waters $(0.15-0.2 \mathrm{M})$ with sandy ground deposits. The structure of the coenoses was from 1 layer, composition consisted from separate groups. Projective vegetation cover was about $75 \%$ (where Potamogeton lucens - 30-40 \%). Lemna trisulca, Myriophyllum spicatum, M. verticillatum, Potamogeton perfoliatus, Utricularia vulgaris, Spirodela polyrrhiza, Hydrocharis morsus-ranae were the species with projective cover 5-10 \%. Nymphaea alba, Nuphar lutea, Batrachium rionii, Salvinia natans, Potamogeton nodosus Poir. were noted as a single specimen in this association.

Elodeetum canadensis association was recorded in shallow waters with sandy lake bed (water depth was $0.8-1.2 \mathrm{M}$ ). The structure of the coenoses was from 1 layer, with uniform composition. Herbage there was dense, projective vegetation cover about 70-80 \% (where Elodea canadensis covered 40-50 \%). From time to time Potamogeton perfoliatus was a subdominant it this association and its projective vegetation cover was up to 20-25\%. Ceratophyllum demersum, Potamogeton crispus L., P. compresus L., Lemna trisulca, Lemna minor, Spirodela polyrrhiza covered up to $5 \%$ of area each.

Ceratophylletum demersi association was less common and occupied sites with sandy lake bed in northern part of the Trubyn Lake (with water depth 1.2-1.5 м). Coenoses were with uniform composition, projective vegetation cover was about $90-100 \%$ with participation of dominant species up to $50-70 \%$. Myriophyllum spicatum was here a subdominant projective cover of which sometimes was up to $30 \%$. Lemna trisulca, Lemna minor, Spirodela polyrrhiza, Utricularia vulgaris, Salvinia natans covered up to $5 \%$ of area each. 
Class Lemnetea de Bolos et Masclans 1955 in Lake Trubyn flora represented by Lemno-Spirodeletum polyrhizae W. Koch 1954, Hydrocharitetum morsus-ranae Van Langend 1935, Hydrocharitio-Stratiotetum aloides (Van Langend. 1935) Westh. (1942) 1946 associations.

Lemno-Spirodeletum polyrhizae association occupied considerable areas in northern part of the lake. Its communities protected from the wind by coastalaquatic shallow waters plants on silty-sandy ground deposits (water depth was 1.0$1.5 \mathrm{M})$. The structure of the coenoses consisted from 2 layers, with uniform sometimes separate group composition. Usually they occupied areas 100-150 $\mathrm{m}$ long in the form of spots. General projective vegetation cover was $100(>100) \%$ (where Spirodela polyrrhiza covered 45-60 \%, Lemna minor 25-35\%, Ceratophyllum demersum 20-25 \%). Lemna minor, Lemna trisulca L., Salvinia natans, Hydrocharis morsus-ranae, Potamogeton natans, Utricularia vulgaris were noted as a single specimen in this association.

Hydrocharitetum morsus-ranae association distributed mostly in northern part of the lake and adjoined in the form of the stripes to monodominant communities Phragmitetum communis and Typhetum angustifoliae. The water depth at the points of its growth was about 0.9-1.5 M, sandy medium silty soils. Coenoses consisted from 2 layers, with uniform composition. General projective vegetation cover was 100 (> 100) \%, with participation of Hydrocharis morsusranae about $80 \%$, Salvinia natans - about $60 \%$, Ceratophyllum demersum-40\%. Spirodela polyrrhiza, Lemna trisulca, Batrachium circinatum (Sibth.) Spach and Nymphaea candida covered up to $5 \%$ of area each. Single specimens of Batrachium rionii (Lagger) Nyman, Elodea canadensis, Utricularia vulgaris, Myriophyllum spicatum, M. verticillatum were noted within this association.

Hydrocharitio-Stratiotetum aloides association exclusively distributed in northern part of the lake. It was confined to shallow waters (water depth 0.6-1.5 m) with silty deposits. Every year the area of these coenoses increase. Right branch actually filled by this association as a result of a general fall of water level in last years and collecting of silty deposits. Coenoses consisted from 2 layers, with uniform composition. Herbage was very very dense, projective vegetation cover was 90-100 (> 100) \%. Submerged and partially above water vegetation levels formed by Stratiotes aloides, its projective cover was about $80-95 \%$ with participation of subdominant Spirodela polyrrhiza about 30-50 \%. Except of subdominant, Hydrocharis morsus-ranae L., Salvinia natans, Lemna trisulca, Myriophyllum spicatum, Utricularia vulgaris grew in above water layer with projection cover up to $10 \%$.

Also within the lake fragments of Salvinio-Hydrocharitetum (Oberdorfer 1957) Boscaiu 1966 and Spirodelo-Salvinietum natantis Slavnić 1956 associations can be found, in which Salvinia natans was a dominant species. More often it appears as subdominant in rare for Polissya (Forest Zone of Ukraine) Salvinio- 
Hydrocharitetum association. Within Trubyn Lake projective vegetaion cover of this association was about $90-100 \%$ (where Hydrocharis morsus-ranae covered 80 $\%$, S. natans $-50-70 \%$ ). Submerged Ceratophyllum demersum (up to $40 \%$ of vegetation cover) and Myriophyllum spicatum (up to $30 \%$ ) were here as codominants. Spirodela polyrrhiza, Lemna trisulca, Nymphaea candida, Batrachium circinatum (Sibth.) Spach, Utricularia vulgaris, Elodea canadensis covered up to 5 $\%$ of area each. This association adjoined as a strip to Phragmitetum communis (Gams 1927) Schmale 1939 and Typhetum angustifoliae Pignatti 1953 communities.

Fragments of Spirodelo-Salvinietum natantis Slavnić 1956 association occupied the small sections in north part of Lake Trubyn. Vegetation cover of such coenoses was about 90-100\%, cover of Spirodela polyrrhiza is 40-50 \%, S. natans - 30-40\%. Also Lemna minor, L. trisulca, L. gibba, Hydrocharis morsusranae, Potamogeton pectinatus, Ceratophyllum demersum, Sagittaria sagittifolia were noted in such communities (vegetation cover of them was up to $5 \%$ ).

\section{Algae and Cyanoprokaryota.}

Oxbow lakes of Desna River are characterized by interesting and unique flora, but their algal flora is poorly known before now and algal floristical studies are very insufficient. Here we present some of our data about algal vegetation and composition of all systematic groups in Lake Trubyn.

172 species (182 intraspecific taxa) of algae and cyanoprokaryota were found in the lake (Table 4). They belong to 92 genera, 14 classes, 32 families, 9 divisions, i.e. Cyanoprokaryota - 22 species (26 intraspecific taxa), Chrysophyta3, Cryptophyta - 2, Dinophyta - 3, Xanthophyta - 7, Rhodophyta - 1, Euglenophyta - 9 (10), Bacillariophyta - 51 (55), Chlorophyta - 74 (75). Following genera were the richest by species diversity (bigger than average index): Gloeocapsa (Kütz.) Hollerb., Nostoc Vauch. ex Born. et Flah., Lyngbya Ag. ex Gom., Cryptomonas Ehr., Euglena Ehr., Cyclotella Kütz., Cocconeis Ehr., Fragilaria Lyngb., Aulacoseira Hon., Coenocystis Korsch., Oocystis A. Br., Acutodesmus (Hegew.) Hegew. et Hanagata, Chlamydomonas Ehr., Oedogonium Link, Staurastrum Meyen s.str., Spirogyra Link (2 species in each genus), Anabaena Bory ex Born. et Flah., Peridinium Ehr., Ophiocytium Näg., Characiopsis Borzi, Phacus Duj., Trachelomonas Ehr., Gomphonema (Ag.) Ehr., Placoneis Mer. emend. Cox, Synedra Ehr., Epithemia Bréb. in Bréb. et God., Coelastrum Näg., Pediastrum Meyen, Tetraedron Kütz., Closterium Nitzsch (in 3), Calothrix Ag. ex Born. et Flah., Oscillatoria Vauch., Eunotia Ehr., Navicula Bory, Scenedesmus Meyen (in 4), Nitzschia Hass. (5), Desmodesmus (Chod.) An, Friedl et Hegew. (6), Cosmarium Corda (10). 
Table (4): Diversity and distribution of algae on different substrates in Lake Trubyn

\begin{tabular}{|c|c|c|c|c|c|c|c|c|c|}
\hline № & Taxa & $\mathbf{1}$ & 2 & 3 & 4 & 5 & 6 & 7 & 8 \\
\hline & CYANOPROKARYOTA & & & & & & & & \\
\hline \multirow[t]{2}{*}{1} & $\begin{array}{l}\text { Anabaena sphaerica Born. et Flah. f. } \\
\text { sphaerica }\end{array}$ & & & & & & + & + & + \\
\hline & A. spaerica f. conoidea Elenk. & & + & & & + & & & \\
\hline 2 & A. hassalii (Kütz.) Wittr. & & & & & & & + & \\
\hline 3 & A. scheremetievi Elenk. & & & & & & + & & \\
\hline 4 & Calothrix braunii Born. et Flah. & + & + & & & + & + & + & + \\
\hline 5 & C. scytonemicola Tild. & & & & & & & & + \\
\hline 6 & C. castellii (Massalongo) Bornet et Flahault & + & & & & & & & \\
\hline 7 & C. adscendens (Näg) Born. et Flah. & & & & & & & + & \\
\hline 8 & Gloeocapsa limnetica (Lemm.) Hollerb. & & & & & & & + & \\
\hline \multirow[t]{2}{*}{9} & G. minor (Kütz.) Hollerb. ampl. f. minor & & & & & + & & & + \\
\hline & G. minor f. dispersa (Keissl.) Hollerb. & & & & & & & & + \\
\hline $\mathbf{1 0}$ & Gomphosphaeria lacustris Chod. & & & + & & & & & \\
\hline 11 & Phormidium frigidum Fritsch & + & & & & & & + & \\
\hline \multirow[t]{2}{*}{12} & $\begin{array}{l}\text { Microcystis pulverea (Wood) Forti emend. } \\
\text { Elenk. f. pulverea }\end{array}$ & & + & & & & & + & \\
\hline & $\begin{array}{l}\text { M. pulverea f. conferta (W. et G.S. West) } \\
\text { Elenk. }\end{array}$ & & & & & & & + & \\
\hline 13 & Nostoc cuticulare Born. et Flah. & & & & & & & + & \\
\hline \multirow[t]{2}{*}{14} & $\begin{array}{l}\text { N. linckia (Roth) Born. et Flah. sensu Elenk. } \\
\text { f. linckia }\end{array}$ & + & + & & & + & & + & \\
\hline & N. linckia f. piscinale (Kütz) Elenk. & & & & & & & + & \\
\hline 15 & Oscillatoria amoena (Kütz.). Gom. & & & & & & + & & \\
\hline 16 & O. planctonica Wolosz. & & & & & & & + & \\
\hline 17 & O. limnetica Lemm. & & & & & & & + & \\
\hline 18 & O. splendida Grew. & + & & & & + & & + & \\
\hline 19 & Lyngbya rivulariarum Gom. & & & & & & & + & \\
\hline 20 & L. epiphytica Hier. & & & & & & & & + \\
\hline 21 & Tolypothrix distorta Kütz. & & & & & & & + & \\
\hline \multirow[t]{2}{*}{22} & Spirulina major Kütz. & & & & & & & + & \\
\hline & CHRYSOPHYTA & & & & & & & & \\
\hline 23 & Dinobryon divergens Imhof & & & & & & & + & \\
\hline 24 & Chrysococcus rufescens Klebs & & & & & & & + & \\
\hline \multirow[t]{2}{*}{25} & Mallomonas acaroides Perty & & & & & & & + & \\
\hline & DINOPHYTA & & & & & & & & \\
\hline 26 & Peridinium cinctum (O. Müll.) Ehr. & & & & & + & & + & \\
\hline 27 & P. palatinum Laut. & & + & & + & & & + & \\
\hline \multirow[t]{2}{*}{28} & P. umbonatum Stein. & & & & & & & + & \\
\hline & CRYPTOPHYTA & & & & & & & & \\
\hline 29 & Cryptomonas obovata Skuja & & & & & & & & \\
\hline \multirow[t]{2}{*}{30} & Cryptomonas sp. & & & & & & & + & \\
\hline & XANTHOPHYTA & & & & & & & & \\
\hline 31 & Ophiocytium lagerheimii Lemm. & & & & & & & + & \\
\hline 32 & O. capitatum Wolle & & & & & & & + & \\
\hline 33 & O. cochleare A. Br. & & & & & & + & & \\
\hline 34 & Characiopsis falx Pasch. & & & + & & & & & \\
\hline 35 & Ch. longipes (Rabenh.) Borzi & & & & & & & + & \\
\hline 36 & Ch. pyrifirmis (A. Br.) Borzi & & & + & & & & & \\
\hline \multirow[t]{2}{*}{37} & Tribonema vermichloris Ettl & & & & & & & & \\
\hline & RHODOPHYTA & & & & & & & & \\
\hline \multirow[t]{2}{*}{38} & Chantransia chalybea (Roth) Fr. & & & & & & & + & \\
\hline & EUGLENOPHYTA & & & & & & & & \\
\hline
\end{tabular}




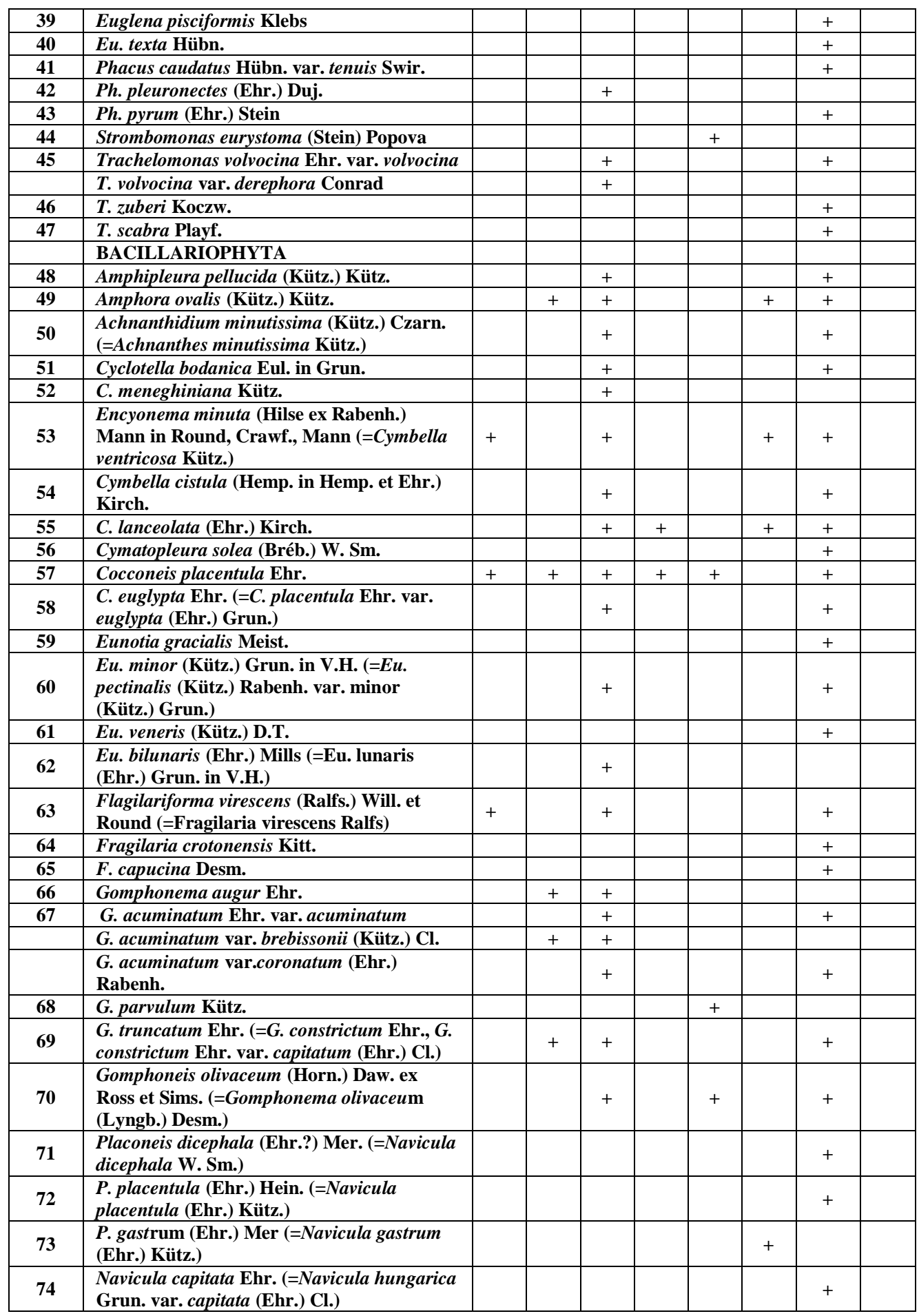

Egyptian J. of Phycol. Vol. 11, 2010

- 144 - 
Algae, cyanoprokaryota and aquatic vegetation of Lake Trubyn (Desna oxbow system, Ukraine)

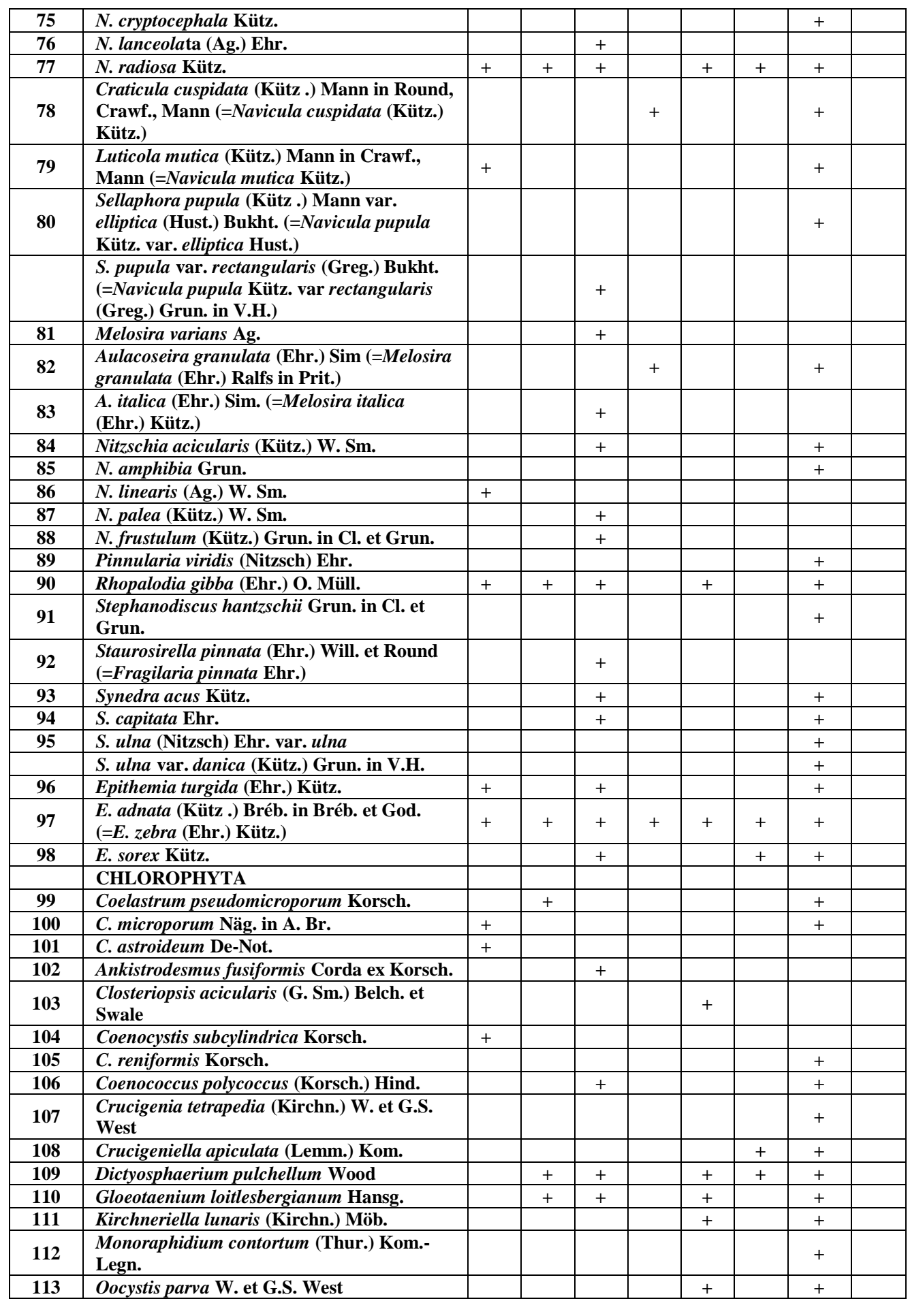

Egyptian J. of Phycol. Vol. 11, 2010

- 145 - 


\begin{tabular}{|c|c|c|c|c|c|c|c|c|c|}
\hline 114 & O. rhomboidea Fott & & & & & & & + & \\
\hline 115 & Palmodiction varium (Näg.) Lemm. & & & & & & & + & \\
\hline 116 & Pediastrum tetras (Ehr.) Ralfs. & + & + & + & + & + & + & + & \\
\hline 117 & P. boryanum (Turp.) Menegh. & & + & + & & + & & + & \\
\hline 118 & P. duplex Meyen & & + & + & + & & + & + & \\
\hline 119 & Pseudocharacium acuminatum Korsch. & & & & & + & & + & \\
\hline 120 & Raphidocelis subcapitata (Korsch.)Nyg. et al. & + & & & & & & + & \\
\hline 121 & Quadricoccus ellipticus Hortob. & & & & & & & & + \\
\hline 122 & Tetrastrum triangulare (Chod.) Kom. & & & & + & + & & + & \\
\hline 123 & Tetraedron mininum (A. Br.) Hansg. & & & + & & & + & + & \\
\hline 124 & T. caudatum (Corda) Hansg. & & & & & & & + & \\
\hline 125 & T. triangulare Korsch. & + & & + & & + & & + & \\
\hline 126 & Sorastrum spinulosum Näg. & + & + & + & & + & + & + & \\
\hline 127 & Selenastrum gracilis Reinsch & & & & & & & + & \\
\hline 128 & $\begin{array}{l}\text { Acutodesmus pectinatus (Meyen) Tsar. } \\
\text { (=Scenedesmus falcatus Chod.) }\end{array}$ & & & & & & + & + & \\
\hline 129 & $\begin{array}{l}\text { A. obliquus (Turp.) Tsar. (=Scenedesmus } \\
\text { acutus Meyen) }\end{array}$ & & & & & + & & & \\
\hline 130 & $\begin{array}{l}\text { Desmodesmus bicaudatus (Deduss.) Tsar. } \\
\text { (=Scenedesmus bicaudatus (Hangs.) Chod.) }\end{array}$ & & & & & & & + & \\
\hline 131 & $\begin{array}{l}\text { D. communis (Hegew.) Hegew. } \\
\text { (=Scenedesmus quadricauda Chod.) }\end{array}$ & & + & + & & & + & + & \\
\hline 132 & $\begin{array}{l}\text { D. subspicatus (Chod.) Hegew. et A. Schidt } \\
\text { (= Scenedesmus sempervirens } \text { Chod.) }\end{array}$ & & & & & & & + & \\
\hline 133 & $\begin{array}{l}\text { D. grahneisii (Heynig) Hegew. } \\
\text { (=Scenedesmus grahneisii (Heynig) Fott et } \\
\text { Kom.) }\end{array}$ & + & & & & & + & & \\
\hline \multirow[t]{2}{*}{134} & $\begin{array}{l}\text { D. opoliensis (P. Richt.) Hegew. var. } \\
\text { opoliensis (=Scenedesmus opoliensis } \mathbf{P} \text {. } \\
\text { Richt.) }\end{array}$ & & & & & & + & + & \\
\hline & $\begin{array}{l}\text { D. opoliensis var. carinatus (Lemm.) Hegew. } \\
\text { (=Scenedesmus opoliensis } \text { P. Richt. var } \\
\text { carinatus Lemm.) }\end{array}$ & & & & & + & & & \\
\hline 135 & $\begin{array}{l}\text { D. magnus (Meyen) Tsar. (=Scenedesmus } \\
\text { magnus Meyen) }\end{array}$ & + & & & & & & & \\
\hline 136 & $\begin{array}{l}\text { Enallax costatus (Schmidle) Pasch. } \\
\text { (=Scenedesmus costatus } \text { Schmidle) }\end{array}$ & & & & & & & + & \\
\hline 137 & Scenedesmus ellipticus Corda & & & & & & + & + & \\
\hline 138 & S. arcuatus (Lemm.) Lemm. & & + & & & + & & + & \\
\hline 139 & $\begin{array}{l}\text { S. parvus (G. Sm.) Bourr. in Bourr. et } \\
\text { Mang. }\end{array}$ & & & & & + & & & \\
\hline 140 & $\begin{array}{l}\text { S. verrucosus Roll (=Scenedesmus } \\
\text { disciformis (Chod.) Fott et Kom.) }\end{array}$ & & & & & & + & & \\
\hline 141 & Heleochloris conica Korsch. & & & & & & + & & \\
\hline 142 & Pandoria charkoviensis Korsch. & & & & & & & + & \\
\hline 143 & P. morum (O. Müll.) Bory & & & & & & & + & \\
\hline 144 & Eudorina cylindrica Korsch. & & & & & & & + & \\
\hline 145 & Phacotus coccifer Korsch. & & + & + & & + & + & + & \\
\hline 146 & Chlamydomonas monadina Stein & & + & & & & & & \\
\hline 147 & Ch. angulosa Dill & & & & & & & + & \\
\hline 148 & Uronema intermedium Bourr. & & & & & & & + & \\
\hline 149 & Aphanochaete repens A. Br. & + & & + & & & & + & \\
\hline 150 & Cladophora sp. & & & & & & & + & \\
\hline 151 & Oedogonium sp.1 & + & + & + & & + & + & + & \\
\hline 152 & Oedogonium sp.2 & & & & & & + & & \\
\hline 153 & Closterium parvulum Näg. & & & & & & & & + \\
\hline 154 & Cl. pronum Bréb. & & & & & & & + & \\
\hline
\end{tabular}

Egyptian J. of Phycol. Vol. 11, 2010

- 146 - 
Algae, cyanoprokaryota and aquatic vegetation of Lake Trubyn (Desna oxbow system, Ukraine)

\begin{tabular}{|c|c|c|c|c|c|c|c|c|c|}
\hline 155 & Cl. leibleinii Kütz. & & & & & & & + & \\
\hline 156 & Gonatozygon monotaenium De Bary & & & + & & & & + & \\
\hline 157 & Cosmarium impressulum Elfv. & & & & & & & + & \\
\hline 158 & C. punctulatum Bréb. & & & & + & + & & & \\
\hline 159 & C. rectangulare Grun. & & & & & & & + & \\
\hline 160 & C. subprotumidum Nordst. & & + & & & & & & \\
\hline 161 & C. venustum (Bréb.) Arch. & & & + & & & + & + & \\
\hline 162 & C. granatum Bréb. & & & + & & & + & & \\
\hline 163 & C. botrytis Menegh. & & & + & & & & & \\
\hline 164 & C. humile (Gay) Nordst. & & & & & + & & & \\
\hline 165 & C. meneghinii Bréb. & & & & & + & & & \\
\hline 166 & Cosmarium sp. & & & & & & & + & \\
\hline 167 & Staurastrum crenulatum (Näg.) Delp. & & & & & & + & & \\
\hline 168 & St. paradoxum Meyen & & & + & & & & & \\
\hline 169 & $\begin{array}{l}\text { Raphidiastrum granulosum (Ehr.) Pal.- } \\
\text { Mordv. }\end{array}$ & & & & & & & + & \\
\hline 170 & Xanthidium bifidum (Bréb.) Pal.-Mordv. & & & & & + & & + & \\
\hline 171 & Spirogyra sp.1 & + & & + & & & + & + & + \\
\hline 172 & Spirogyra sp.2 & & & & & & & & + \\
\hline \multicolumn{2}{|r|}{ IN TOTAL (species/intraspecific taxa) } & $\begin{array}{l}26 / \\
26\end{array}$ & $\begin{array}{l}26 / \\
26\end{array}$ & $\begin{array}{l}58 / \\
59\end{array}$ & $\begin{array}{l}10 / \\
10\end{array}$ & $\begin{array}{l}34 / \\
34\end{array}$ & $\begin{array}{ll}32 / \\
32\end{array}$ & $\begin{array}{l}123 / \\
127\end{array}$ & $\begin{array}{l}9 / \\
10\end{array}$ \\
\hline
\end{tabular}

Notes: 1 - on roots and on edge of Myriophyllum spicatum L. leaves; 2 - on roots of Salvinia natans; 3 on Ceratophyllum demersum L; 4 -on edge of Lemna trisulca L. leaves; 5 - in between Lemna trisulca and Cladophora sp.; 6 - on surface of leaves and in scrapings from leafstalk of Potamogeton lucens L., 7 - plankton, 8 - combined sample.

Calothrix castellii (Massalongo) Bornet et Flahault and Tribonema vermichloris Ettl were found for the first time in Ukraine, Characiopsis falx Pasch., Chantransia chalybea (Roth) Fr., Coenocystis reniformis Korsch., Gloeotaenium loitlesbergianum Hansg., Oocystis rhomboidea Fott, Pseudocharacium acuminatum Korsch., Uronema intermedium Bourr., Raphidiastrum granulosum (Ehr.) Pal.-Mordv., Xanthidium bifidum (Bréb.) Pal.Mordv. were the most interesting findings for Ukrainian algal flora.

\section{Conclusions}

Thus, we obtained baseline data on diversity, floristic composition and vegetation of aquatic and coastal-aquatic higher plants, as well as algae and cyanoprokaryota of Lake Trubyn. We conducted floristic, ecological analyses and analyze of lake vegetation. We made some changes and additions to the vegetation map of the lake because for more than 20 years borders and distribution of many associations have changed. For the first time we proposed scheme of coenoses distribution of northern part of the lake near northern neighborhood of Grushivka village. This information can be used in the implementation of monitoring studies of Lake Trubyn ecosystems.

\section{References}

Algae. Reference book (1989) / S.P.Wasser (ed.), Kiev: Naukova dumka: 1-608 (in Russian). 
Balashov, L. S.; Semenikhin, V. I.; Semenikhina, K. A. and Dubyna, D. V. (1980). Distribution of genus Myryophyllum L. in Ukraine, its ecology and coenology. Ukr. Botan. J., 36(6): 30-35 (in Ukrainian).

Belavskaya, A. P. (1979). On methodic of study of higher aquatic vegetation. Botan. J., 64(1): 32-42 (in Russian).

Geographical Encyclopedia of Ukraine (1989). Kiev, Ukr. Rad. Encycl. Publ. House, vol.1: 316-317 (in Ukrainian).

Geographical Encyclopedia of Ukraine (1993). Kiev, Publishing House Ukr. Encycl. named after M.P. Bazhan, vol.3: 308 (in Ukrainian).

Guide of fresh-water algae of Ukrainian SSR. (1938-1994). Kyiv, Naukova dumka, Vol. 1-12. (in Ukrainian).

Desna within borders of Ukraine (1964). Kiev, Naukova Dumka Publishing House, 1-160 (in Ukrainian).

Dubyna, D. V. (2006): Higher aquatic vegetation. Kiev, Pfitosociocenter, 1-412 (in Ukrainian).

Dubyna, D. V. and Moroz, S. V. (1977). Nymphoides peltata (S. Gmel.) Kuntze. in Ukraine. Ukr. Botan. J., 34(4): 398-402 (in Ukrainian).

Dubyna, D. V. and Semenikhina, K. A. (1978). Trapa natans L. in Desna River. Ukr. Botan. J., 35(4): 371-374 (in Ukrainian).

Elenkin, A. A. (1938-1949). Blue-green algae of USSR, special part 1, 2. Izd. AN SSR, Moscow-Leningrad: 1-1908 (in Russian).

Geitler, L. (1932). Cyanophyceae. In: Rabenhorst's Kryptogamen-Flora. Acad. Verlagsges., Leipzig., 14: 1-1196 (in German).

Hejny, S. (1981). Klasifikace vodnich a bazinnych spolecenstev makrofit y Ceskoslovensku. Zpr. Cs. hot. spolec., 16(2): 71-87 (in Czhech).

Huber-Pestalozzi, G. U. A. (1969). Das Phytoplankton des Süsswassers, Systematik und Biologie, Part 4: Euglenophycean. E. Schweizerbarth'sche Verlagsbuchhandlug (Nagele u. Obermiller), Stuttgart: 1-606.

Huber-Pestalozzi, G. U. A. (1972). Das Phytoplankton des Süsswassers, Systematik und Biologie, Part 6: Fott. Bohuslav: Chlorophyceae (Grunalgen), Ordnung Tetrasporales. E. Schweizerbarth'sche Verlagsbuchhandlug (Nagele u. Obermiller), Stuttgart: 1-116.

Huber-Pestalozzi, G. U. A. (1983). Das Phytoplankton des Süsswassers, Systematik und Biologie, Part 7, Teil 1: Komarek, J. und B. Fott: Chlorophyceae (Grunalgen), Ordnunug Chlorococcales. E. Schweizerbarth'sche Verlagsbuchhandlug (Nagele u. Obermiller), Stuttgart: 11044.

Katanskaja, V. M. (1981). Higher aquatic vegetation of inland waters of USSR.: Leningrad, Nauka Publishing House: 1-187 (in Russian).

Mulyarchuk, S. O. (1980). Vegetation of Chernigiv Region. Kiev, Vyscha Shkola Publishing House: 1-202 (in Ukrainian). 
Potulnytsky, P. M.; Pogrebennyk, V. P. and Kucherjava L. F. (1973). Ecological typology of macroliths. Ukr. Botan. J., 30(5): 584-590 (in Ukrainian).

Red Data Book of Ukraine (2009). Ya.P. Didukh (ed.). Kiev: Globolconsalting: 38 (in Ukrainian).

Semenikhina, K. A. (1979). New findings of rare aquatic species in oxbow water bodies of Desna River. Ukr. Botan. J., 36(3): 214-218 (in Ukrainian).

Semenikhina, K. A. (1982). Coastal-aquatic and aquatic flora of Desna River and water bodies of its flood-lands within USSR. Ukr. Botan. J., 39(1): 34-36 (in Ukrainian).

Semenikhina, K. A. (1982a). Aquatic vegetation of Desna River and water bodies of its flood-lands within USSR. Ukr. Botan. J., 39(2): 57-62 (in Ukrainian).

Shelyag-Sosonko, Yu. R. and Semenikhina, K.A. (1984). Vegetation of Vaden' and Trubyn Lakes (Desna flood-lands). Ukr. Botan. J., 41(3): 28-33 (in Ukrainian).

Vakulenko, N. I. (1935). On study of higher aquatic plants of Desna River water bodies. Collection of Papers of Hydrobiol. Station of USSR Academy of Sci., 10: 181-189 (in Ukrainian).

$$
\begin{aligned}
& \text { الطحالب و بدائيات النوة السياتية والنباتات المائية لمنطقة بحيرة تربين }
\end{aligned}
$$

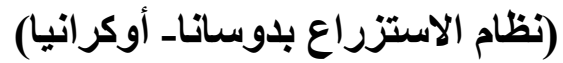

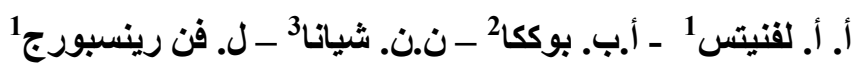

$$
\begin{aligned}
& \text { 1- قسم النباتـ مدرسة العلوم البيئية والتطور - جامعة شمال شرق بوتكافستروم } 2520 \text { جنوب /فريقيا } \\
& \text { 2- قسم النباتـ كلبة علوم الحياة - جامعة ف بن. كريزين كروكوف الوطنية ـ كرهركوفـ اوكرانيا } \\
& \text { 3- أكاديمية العلوم الطبيعية معطر م.ج. كوهولدين لعلم النبات - وكراني }
\end{aligned}
$$

تم فى هذه الدراسة وضع الخطوط الاساسية للتنوع وتركيب النباتات المائية و الطحالب التى تتشكل

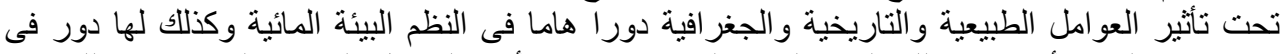

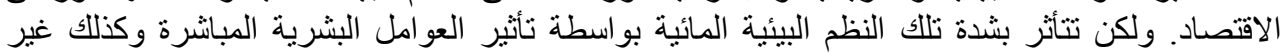

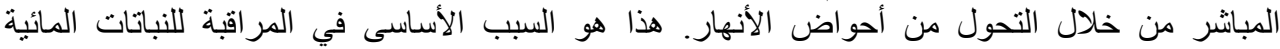

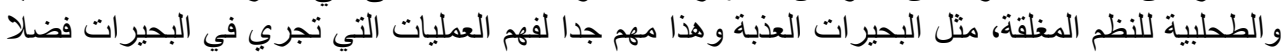
عن التكهن العلمي لتغير ات النظم البيئية البحيرة. 